DOI: 10.2478 /ausp-2019-0029

\title{
Lexical Emphasis in the Literary Dialogue: A Translational Perspective
}

\author{
Mona ARHIRE \\ Transilvania University of Braşov \\ Department of Theoretical and Applied Linguistics \\ mona.arhire@unitbv.ro
}

\begin{abstract}
Emphasis is largely associated with the expression of emotional involvement in speech acts in general. In the fictional dialogue, the relevance of emphasis is multiplied due to several considerations. Firstly, the emphatic utterances impact the emotional content of the text and affect its style and reception. Secondly, it is the compromises and the careful linguistic and stylistic choices that authors have to make in order to effectively render the emphasis typical of speech in the written mode. Thirdly, if a work of literature is translated, the emphasis that the dialogue displays is to be equally forceful in its target language version. With these considerations in view, the study sets out to examine the possibility of obtaining a similarly emphatic content of an English source text in translational Romanian by means of lexical items. To this end, a relevant number of emphatic dialogic instances have been depicted for analysis from John Fowles's novel Mantissa and from its translation into Romanian. The objectives of this study are to identify the level of equivalence in the two versions of the novel and to shed a comparative light on the lexical means that lead to the realization of emphasis in English and Romanian.
\end{abstract}

Keywords: literary dialogue, emphasis, translation, lexical items

\section{Introduction}

Fictional dialogue has been subject of research from many vantage points, having been scrutinized within areas pertaining to literary studies, such as stylistics, narratology, or critical analysis, or within disciplines related to language studies and linguistics such as discourse analysis, pragmatics, sociolinguistics, etc. The study presented in this paper focuses on the stylistic load embedded in the literary dialogue of John Fowles's novel Mantissa. More precisely, it looks into the manifestation of emphasis by lexical means in the English original version and the way the emphatic load has been transferred to the Romanian translated version. Hence, the main objective of this study is to identify the level of 
equivalence in the two versions of Fowles's novel and the way lexical emphasis manifests in the two languages.

Methodologically speaking, this study adopts a comparative approach to emphasis as exhibited in the translation of emphatic language instances of fictional work. Emphasis is a carrier of emotional content and of the stylistics of a literary work, which are essential contributors to the way the work is received by the readership of the original and its translated version. The investigation uses as starting and reference point the manifestation of emphasis in English and proposes a comparison of its expression in Romanian meant to enable the creation of a similarly intense effect in the target text. In order to do so, a relevant number of examples is depicted for a comparative analysis which follows and adapts a classification of emphatic devices in English.

This approach is motivated by the recognition of the importance of emphasis in Fowles's novel, which has substantial bearing upon the stylistic value of the text but also on the construction of its social context. Emphasis occupies a central position in the creation of the novel's specificity provided by the dialogue as a creator of atmosphere, tension and an exhibitor of the characters' individual personalities but also the relationship between them, along with the intensity of their feelings, the strength of their opinions and arguments, their state of mind, etc.

Given all this, the study herein necessarily borrows elements from dialogue studies, sociolinguistics, and stylistics, which provides it with a rewarding interdisciplinary character.

\section{Theoretical considerations}

\subsection{Emphasis in the literary dialogue}

Genette claims that experimenting with the speech of literary characters is "one of the main paths of emancipation in the modern novel" (Genette 1980: 173), and Thomas (Thomas 2012) similarly considers that experiments with dialogue are a key constituent of modernist and postmodernist literature. Thomas's argument relies on the fact that dialogue is essential in advancing the plot and exhibiting information about the heroes' actions, who are thereby introduced to the readership as part of the social environment they belong to. The same scholar even praises some authors' success deriving from their skill to have their ear fine-tuned for dialogue (Thomas 2012). The large variety of devices adopted by prose writers to do so has been discussed by many scholars in the last few decades, along with the quality of these devices to expose the stylistic content and specificity of the literary characters' speech (Bishop 1991, Fludernik 1993, Herman 2006, Kinzel-Mildorf 2012, Thomas 2012, etc.). 
Emphasis is the focus of this study as a means of rendering information about the nature of the characters but most of all as a reflection of their state of mind, reactions, and opinions. All this entails considerable expressiveness and display of feelings. The heroes' opinions - especially the ones contradicting the previous speaker's intervention - are oftentimes accompanied by firmness and intense feelings. In expressing such positions in the characters, the dialogue resorts to various stylistic devices, among which emphasis stands out in various facets. Apart from its being a significant way of mirroring the heroes' states of mind, emphasis is also a powerful stylistic means and a significant contributor to creating atmosphere and effect.

This, in its turn, impacts the readers' perception and ultimately, as a feature of style, the author's reception. Among the particular features of Fowles's style in Mantissa that are subject to the readers' perception and the author's reception, most striking are the vividness and the tension of the dialogue. The fast reading and intense effect that these features trigger are "technically" achieved by short and often contradictory replies, which are sometimes interrupted by significant, heavy, and contemplative silence. The auctorial voice is scarce, and the novel is almost in its entirety made up of dialogue, which provides indirect but relevant clues to the interacting characters and the plot. The emphasis embedded in the dialogic utterances does not only provide implicit information about an individual's state of mind, but it also reveals a broader social context which includes relationships between the interacting characters. For instance, violent negation or disapproval can indicate either a close relationship between the speakers or rudeness. In its turn, emphatic disapproval often sounds exaggerated and can entail an ironical attitude. Additionally, such dialogue provides inference of the heroes' belonging to a social class, their level of education but also their thoughts, feelings, desires, etc. This unmediated manner of disclosing the characters' nature, with minimal auctorial contribution, calls for an active and creative stance in the readership, who cannot remain detached.

It is the realm of sociolinguistics that enlightens us on the fact that "[t]he way people use language in different social contexts provides a wealth of information about the social relationships in a community, and the way speakers signal aspects of their social identity through their language" (Holmes 2008: 1). The close relation between language and social context has been tackled quite extensively by scholars such as Bell (1976), Hudson (1996), Bonaffini (1997), Trudgill (2000), Gardiner (2008), Holmes (2008), Spolsky (2010), Wardhaugh (2010), etc. All the feelings and thoughts emerging from the dialogue in association with the extensive use of emphasis are the core creators of atmosphere and effect, thereby having important bearing upon the stylistics of Fowles's work. 


\subsection{Types of emphasis}

Swan (2009: 164-166) distinguishes four types of emphasis in English: (1) emotive and contrastive emphasis, (2) pronunciation: stress, (3) vocabulary: special words, and (4) structures. The first three of them are of interest in this study.

Emotive emphasis occurs when a speaker intends to express strong feelings about some content of an utterance. In contrastive emphasis, strong feelings are also present, but they are accompanied by the expression of a contrast in relation to the interlocutor's previous statement. They can indicate "a contrast between, for example, true or false, or present and past, or a rule and an exception" (Swan 2009: 165).

Additional stress can be added to words in speaking by pronouncing them with a higher intonation or in a louder voice. This can be marked in the written discourse by using italics, bold type, underlining, or capital letters. Alternatively, auxiliary verbs can be added to produce emphasis in such sentences where auxiliaries are not normally used (e.g. He does like it.) or in utterances where they are present to form the continuous or perfect aspect; for instance, auxiliaries are the ones taking over the stress which might extend over the entire sentence.

Lexical items, such as so, such, really, totally, just, etc., can be added to display emphasis as well as swear words or informal expressions. Strong surprise or disagreement can be revealed in questions such as What on earth...?, What the hell...?, etc. (Swan 2009: 165).

Indeed, as will be demonstrated below, emphasis is achieved by several lexical means, all of which ultimately trigger some stylistic effect.

\section{The translation of emphasis: Analysis}

Mantissa by John Fowles (1982) displays a dramatic content that is generated by the tense conversation between the two characters, a writer and his muse. The relationship between them is expressed as an ongoing controversy in an exchange of wits, which frequently employs emphasis. This plays an important role in the creation of a high degree of emotional involvement present in the verbal interaction, which justifies a systematic approach to the investigation of the variety of emphatic devices.

This section presents the analysis of a considerable number of examples of emphatic utterances occurring in dialogues between characters of Fowles's novel (1982). The selection of the examples relied on criteria relative to relevance and diversity in the attempt to cover as many instances of emphasis. The investigation sets off by broadly and partly pursuing Swan's (2009) classification as presented in the previous section. Nevertheless, the classification has been altered and 
completed with additional means of emphasis identified in the fictional dialogues under scrutiny. Each example is accompanied by its translation into Romanian by Angela Jianu (1995) and by comments regarding the equivalence of the emphatic value in the source-language text and in the target-language text.

To start with, for the sake of illustrating the emphatic density bringing about tension and vividness in the dialogue, here is an example which is deemed representative for Fowles's style, exhibiting several means of emphasis (bold type is added by the author of this paper to highlight the emphatic lexical items, whereas italics are taken over from the original text):

(1) "Oh sure. And your name isn't Erato and _"

"No, my name is not Erato! And you're absolutely right. Of course satyrs are pure myth. Of course that grotesque scene never took place. Especially as it involved not one, but two entirely mythical beings." (1982: 43)

- Bine, bine. Adică, nu te cheamă Erato şi ...

- Nu, nu mă cheamă Erato! Şi ai perfectă dreptate. Sigur că satiri nu există decît în mitologie. Sigur că scena aia grotescă n-a avut loc niciodată. Mai ales că nu era vorba de un singur personaj mitologic, ci de două. (1995: 111)

This example depicts only two dialogic turns, which display a variety of emphatic means most of which are of lexical and syntactic nature, but which comprise also purely stylistic devices and punctuation. A closer look reveals adverbial intensifiers (absolutely, especially, entirely), adjectives with intense connotation (pure, grotesque), strings of short, tensed elliptical sentences, noncontracted negation (my name is not Erato), a negative emphatic structure (not one, but two), repetition (of course), an interjection (Oh sure), italics to mark a stress in pronunciation (Of course), and punctuation (an exclamation mark). In Romanian, most of the emphatic lexical means have been taken over as such or replaced by others: e.g. repetition seems to prevail.

\subsection{Emotive and contrastive emphasis}

Contrastive emphasis is quite frequent as a natural manifestation of the characters' constant disagreements. But disagreement here is rarely neutral. In the dialogues at hand, it is often enforced by additional lexical items, which provides the expression with a strong emotional load. Here are a few examples thereof:

(2) "I've never denied it."

"Oh yes you have. Every time you open your stupid mouth." (1982: 30)

- Da' eu n-am negat niciodată asta. 
- O, ba cum să nu. O faci de fiecare dată cînd deschizi gura aia neghioabă. (1995: 78)

The strong disagreement is additionally stressed by means of lexical items such as the interjection $\mathrm{Oh}$, the adverbial every time, and the adjective with strong negative connotation used as offence: stupid. All of them have similar ways of expression in Romanian, the target-language version succeeding thus to preserve the emphatic content of the original. Even more, the translator's awareness of the necessity to reveal the emphatic emotive contrast is obvious in the negative expression $(O$, ba cum să nu), which is not only very natural but also stronger than its faithful affirmative version would have been.

Emphatic equivalence is obtained in the next example as well, where the contrastive emphasis is enforced by repetition, an intensifying adverb, and a noncontracted negation. Out of these emphatic devices, only the one using the noncontracted negation in English is not transferred to Romanian due to the structural mismatch between English and Romanian. Practically, the dialogue is entirely and similarly emphatic in both languages, which makes the bold type cover it entirely:

(3) "You know perfectly well why."

"No. I do not know why." (1982: 16)

- Ştiți foarte bine de ce.

- Nu. Nu ştiu de ce. (1995: 41)

As compared to the previous example, the next one does not use a negation to express contrastive emphasis, but the author resorts to italics to mark a phonological stress, which carries the contrastive meaning:

(4) "I adore it when you pretend to be angry."

"I am angry." (1982: 42)

- Te ador cînd te prefaci furioasă.

- Păi, chiar sînt furioasă. (1995: 110)

The emphatic auxiliary marked as such by the use of italics is not stressed in the Romanian translation, but it is compensated for by the adverb chiar 'indeed'.

The repetition of the word angry adds up to the emphatic value as does its repeated counterpart furioasă in Romanian.

Just as in Example (4), the translation of the following instance does not use italics to mark the stress. Instead, the translator opts for double quotation marks. Even if double quotation marks are not normally used in Romanian to mark emphatic pronunciation and seem rather inappropriate, they may have the power to take over the emphasis: 
(5) "Do you know who ... what I was?"

"Am." (1982: 10)

- Ştiți cine ... ce eram înainte?

- „Cine sînt.” (1995: 22)

\subsection{Emphasis realized by pronunciation markers}

As has been anticipated in examples (4) and (5) above, pronunciation markers are employed in Fowles's original to produce a phonological type of emphasis, which is typically a speech marker. Such pronunciation markers are very frequent in Fowles's Mantissa and very important in delivering the intensity of the characters' feelings in their highly intellectual dialogic interaction in which opinions are often contradictory and almost never neutrally expressed.

As compared to the two translations above, which involve a means of compensation in Romanian, the following ones do not take over the italics and do not employ any means of compensation, as it happens with most of the italicized words. This reduces the intensity of the entire utterance and of the speaker's emotional involvement. In its turn, this determines a more neutral and detached reading of the target-language version and, considering the frequent occurrence of this phenomenon, it affects the overall atmosphere and the generally present tension between the characters:

(6) "We're married. We have children. You must remember that." (1982: 7) - Suntem căsătoriți. Avem şi copii. Nu se poate să nu-ți aduci aminte. (1995: 16)

(7) "Oh where is that nurse." (1982: 10)

- Pe unde-o fi umblând sora? (1995: 23)

(8) “And will you please stop asking these pointless questions." (1982: 14)

- Şi, vă rog, nu mai puneți asemenea întrebări fără rost. (1995: 31)

\subsection{Lexical emphasis proper}

The dialogues abound in adverbial intensifiers, which definitely contribute essentially to the emphatic character of the heroes' speech. Nevertheless, apart from the wealth and the wide variety of the adverbial intensifiers, the use of low-frequency adverbs has an important intensifying role as well. Some of the intensifying adverbs are used metaphorically and seem exaggerated or are used ironically. Romanian proves to possess similarly rich means of adverbial intensifying expressions, what usually makes the translations equivalent both in meaning and in effect: 
(9) "Truly sorry." (1982: 31)

- Zău că-mi pare rău. (1995: 79)

(10) "That's definitely two." (1982: 32)

- Acum sunt două, clar. (1995: 82)

(11) "It's obviously escaped your notice..." (1982: 45)

- Este evident că a scăpat observației tale... (1995: 119)

(12) "She was an extremely superfluous idea from the beginning." (1982: 75)

- A fost o idee cu totul superfluă de la bun început. (1995: 190)

If the previous four examples comprised fairly common intensifiers which display also a quite faithful semantic match, the following ones are less predictable and therefore more forceful:

(13) "How unspeakably vulgar you are sometimes." (1982: 34)

- Cît de înfiorător de vulgar poți fi uneori. (1995: 89)

This is not a literal translation of unspeakably into Romanian, but înfiorător 'dreadfully', 'terribly' is a suitable contextual equivalent that triggers a similar effect in Romanian.

A fully faithful translation has been opted for in the following example:

(14) "You are unimaginably insensitive." (1982: 74)

- Eşti neînchipuit de lipsit de sensibilitate. (1995: 190)

The adverb in Example (15) is metaphorical and additionally entails a witty play upon words since one of the characters played an immortal goddess:

(15) "Immortally offended." (1982: 33)

- Jignită de moarte, aşa nemuritoare cum sînt. (1995: 86)

Its translation has been well inspired by a quite common figurative Romanian phrase de moarte 'mortally'. Although it is a naturally sounding intensifying expression, it omits the key idea of immortality, which is nevertheless compensated for by the addition of aşa nemuritoare cum sînt 'as immortal as I am'. So, the full back translation would be: "Mortally offended, as immortal as I am."

Other dialogic turns involve a double adverbial intensification as in the following two examples:

(16) “This really is a heavenly color." (1982: 52)

- Ce culoare divină. (1995: 135) 
Interestingly, the translation of this example does not employ two adverbs but uses a syntactic change to compensate for the emphasis realized by the English adverb "really", whose translation it omits. The syntactic structure is that of an exclamatory question: Ce culoare divină. The back translation of this utterance is "What a heavenly colour".

The double adverbial intensification is perfectly preserved in Romanian in the following example, which is structurally equivalent as well:

(17) "You have absolutely no feeling for my feelings at all.” (1982: 34)

- Nu-ți pasă absolut deloc de sentimentele mele. (1995: 89)

In the following example, the negative connotation of the adjective "awful" is doubled by another adjective preceding it, "bloody". This is faithfully translated into Romanian:

(18) "It was a bloody awful flight." (1982: 34)

- Zborul pînă aici a fost al naibii de greu. (1995: 89)

As can be inferred from the examples above, although intensifying adverbs can and have been suitably translated into Romanian, some of them have been omitted for no apparent reasons. This might trigger a reduced impact of the targetlanguage version:

(19) "And as for that infantile and totally gratuitous bit of smut about my exposing myself to..." (1982: 70).

- Cît despre episodul ăla infantil, gratuit şi vulgar în care eu, chipurile, mă expun la... (1995: 180)

(20) “Miles, I warn you. You are on the very edge of a precipice.” (1982: 71)

- Miles, te previn. Te afli la marginea unei prăpăstii. (1995: 183)

Apart from adverbial intensifiers, sometimes idiosyncratic speech markers characterize some hero's speech. "Of course" is often used for disconfirmation in negative utterances or for emphatic confirmation in positive ones. Here is an example of each:

(21) "I'm not going to be sidetracked."

"Of course not. I just wondered." (1982: 31)

- Să ştii că n-am de gând să mă lansez în divagații.

- Sigur că nu. M-am întrebat şi eu aşa. (1995: 81)

(22) "Is that all that happened?"

"Of course it was all that happened." (1982: 32) 


\section{- Asta-i tot?}

- Bineînțeles că asta-i tot. (1995: 81)

In the latter example, (22), "of course" is accompanied by repetition and thus strengthened.

Sometimes interjections are naturally employed in order to express contrastive emphasis:

(23) "I've never denied it."

"Oh yes you have. (1982: 30)

- Da' eu n-am negat niciodată asta.

- O, ba cum să nu. (1995: 78)

Adjectives are also often used for the sake of emphasis. "Single" is emphatically used both in affirmative and in negative sentences instead of "any". In Example (24) below, the adverb now in italics is additionally used to threateningly highlight the immediate effect of a major decision:

(24) “One single word and it ends now!" (1982: 33)

- Încă o vorbă şi s-a terminat! (1995: 85)

(25) “There hasn’t been a single mention of it before this.” (1982: 35)

- N-ai pomenit nici măcar o dată de asta pînă acum. (1995: 92)

"Single" is not translated by its primary Romanian equivalent (singur) in either of the sentences above. Instead, the translator opted for the alternative Încă $o$ vorbă 'another word' in the affirmative sentence, as in Example (24), and for nici măcar o dată 'not even once' in the negative utterance as in (25). Both are suitable in Romanian, as well as semantically and stylistically equivalent.

Determiners have also been used by Fowles for emphatic purposes. "So" and "such" have a well-known intensifying value:

(26) "It’s so unfair." (1982: 33)

- E-aşa de nedrept. (1995: 87)

It is obvious that "so" has the meaning of "very" and strengthens the semantic content of the adjective it precedes. Its translation into Romanian follows the same structural pattern.

In contrast, "such" engages in an elliptical construction which precedes a noun here while omitting a possible adjective and thus creating an emphatic effect. This effect might be perceived even stronger with ellipsis than an explicit 
adjective. It is the case of the following example in which other intensifying lexical items are also present:

(27) "In my entire four thousand years I've never met such arrogance. And the sheer blasphemy!" (1982: 33)

- De patru mii de ani de cînd exist pe pămîntul ăsta n-am mai pomenit atîta aroganță. Şi ce blasfemie! (1995: 85)

The translation of "such arrogance" follows the constructive manner of the original version and can be back-translated as "so much arrogance", which is identical with its meaning in English.

Strong feeling is oftentimes revealed by means of intensifying expressions, which most of the times occur in interrogatives, sometimes rhetorical ones, to express strong discontent or disbelief:

(28) “Then who the devil do you think you are?" (1982: 43)

- Atunci cine dracu' te-oi fi crezînd? (1995: 112)

(29) “And how on earth can a harem be putrid?" (1982: 44)

- Şi cum naiba poate un harem să fie putred? (1995: 114)

Strong annoyance can also be expressed as in the following affirmative sentences:

(30) "All right. I may, heaven knows why, out of some misguided sense of responsibility, have inspired you with the mere gist of a notion of some new sort of meeting between us." (1982: 33)

- De acord. Poate că, întradevăr, Dumnezeu ştie cum, dintr-un simț al răspunderii prost ți-am inspirat fie şi numai în linii generale ideea unei întîlniri de alt gen între noi doi. (1995: 86-87)

(31) "You damn well exist for me, anyway." (1982: 44)

- La naiba, da' pentru mine exişti oricum. (1995: 117)

(32) "And for God's sake stop staring at me like a dog waiting for a bone." (1982: 36)

- Pentru numele lui Dumnezeu, nu te mai uita la mine ca un cățel care aşteaptă un os. (1995: 94)

All the expressions above, in examples (28)-(32), have good equivalents in Romanian, which possesses similar phrases, also commonly used for the sake of emphasis in the expression of intense feelings, especially negative ones. 


\section{Findings}

The selected examples and their preliminary analysis enabled a possible classification of lexical means of emphasis, which is nevertheless limited to the resources provided by the nature of the dialogue comprised in the novel Mantissa by John Fowles. Roughly speaking, there are two categories of lexical emphasis, one that uses or adapts lexical items to determine or enhance emphasis (as in sections 3.1. and 3.2.) and one in which those lexical items or phrases are used whose connotation is emphatic or becomes contextually emphatic (as in Section 3.3.).

The first section of the analysis looked into the expression of emotive and contrastive emphasis in English and its translation into Romanian. The findings exhibit that strong and emotionally charged disagreements are given not only by the contrast proper (which can be neutral) but by additional emphatic lexical items. That is, the contrastive utterances "oh, yes" or "oh, no" are emotionally loaded by supplementary lexical means (e.g. "every time" or the strong negative adjective "stupid" addressed as offence). In matter of translation, there are good equivalents in Romanian and the emphatic content can be and has been well preserved in the Romanian target-language version.

Further on, attention has been granted to emphasis simply realized by adding pronunciation markers to lexical items so as to stir an emphatic reading. Italicized words occur very frequently in Fowles's dialogues, and they do bear important stress. The Romanian version too often omits this formal addition, which brings about a loss in emotional intensity, affecting both the stylistics of the target text and the social context.

Finally, lexical emphasis proper was the most resourceful section due to the variety of emphatic means it exhibited. As derived from the scrutinized source-language text, they range within a number of grammatical categories or are expressions commonly used to display emotions. We have identified (in 3.3.) a wealth of adverbial intensifiers, adverbial idiosyncratic speech markers (such as "of course"), interjections, adjectives with strong connotation or added to intensify the stress and determiners. Additionally, we could observe several expressions (e.g. "for God's sake") used to add force to a question or a request, to express annoyance, surprise, anger, frustration, etc.

These expressions are important also for their rendering information about the social context - namely, being typical of the common, familiar register, they indicate that there is a close relationship between the characters, so close that they can afford to express their thoughts and feelings very naturally, being at times even impolite or offensive to each other. No less is this valid for Romanian and the target-language version. Thus, Romanian does possess means to equivalate English emphasis in terms of lexical connotation and the stylistic effect produced. 


\section{Conclusions and further research}

Fowles's novel offers a wealth of emphatic devices that provide information about the novel's social context: information about the characters individually, their temporary state of mind but also about the relationship between them and its change in the evolution of the contextual situation. It can be safely stated that emphasis is a major stylistic device in this work of fiction, an intrinsic creator of atmosphere which considerably operates at the reception level. The constant tension and vividness that impact the reading derive mainly from the intellectual and heavily contradictory dialogue in which the heroes hold firm positions, express opinions and beliefs, and exhibit strong feelings.

This justifies this undertaking that can be useful in the translation of other literary works the effect of which relies substantially on emphatic language means. It is a matter of contributing to the proper transfer of a writer's style to another language. This further entails not only obtaining the overall equivalence of the work in another language but also enabling the equivalent reading of the work and an equivalent reception of its author by the readership of a target culture.

Even if the study is limited to the language pair English and Romanian and even if it is not exhaustive in terms of the collection of means of emphasis, it can be completed with other relevant devices in further studies. So far, starting from Swan's classification, it enabled an (initial) more refined and nuanced classification of means of emphasis that occur in the fictional dialogue. Structural emphasis has not been subject to this investigation, but it is a necessary addition with a view to completing the conclusions and providing an overall comparative account of the manifestation of emphasis in English and Romanian. Furthermore, a thorough examination of structural means of emphasis is expected to display a wider contrastive array than the investigation of lexically determined emphasis has. So, structural emphasis, but also stylistic emphatic devices proper, will be the focus of a study to complete this one.

Even though Romanian proved similar in the expression of emphasis, sometimes the emphasis was omitted in the analysed dialogues. This has definitely reduced the intensity of the emotion and has sometimes neutralized the stylistic effect. Therefore, awareness of the emphatic devices and of the emphatic effect are essential in the act of translation as well as finding authentic and consistent means of expressing emphasis in the target language so as to mirror the characters' idiosyncratic speech and the author's style. 


\section{References}

Bell, Roger T. 1976. Sociolinguistics: Goals, approaches, and problems. London: Batsford.

Bishop, Ryan. 1991. There's nothing natural about natural conversation: A look at dialogue in fiction and drama. Oral Tradition 6(1): 58-78.

Bonaffini, Luigi. 1997. Translating dialect literature. World Literature Today 71(2): 279-288.

Fludernik, Monika. 1993. The fictions of language and the languages of fiction: The linguistic representation of speech and consciousness. London-New York: Routledge.

Fowles, John. 1982. Mantissa. New York-Boston-London: Little, Brown and Company. 1995. Mantissa. Transl. by Angela Jianu. Bucharest: Univers.

Gardiner, Alan. 2008. English language. London: Pearson Education Limited.

Genette, Gérard. 1980. Narrative discourse: An essay on method. Transl. by Jane E. Lewin. Ithaca: Cornell University Press.

Herman, David. 2006. Dialogue in a discourse. Narrative Inquiry 16(1): 75-84.

Holmes, Janet. 2008. An introduction to sociolinguistics. U.K.: Longman.

Hudson, Richard. A. 1996. Sociolinguistics. Cambridge: CUP.

Kinzel, Till-Jarmila Mildorf. 2012. New perspectives on imaginary dialogues: An interdisciplinary dialogue. In: Till Kinzel-Jarmila Mildorf (eds), Imaginary dialogues in English: Explorations in a literary form. Heidelberg: Universitätsverlag Winter. 9-30.

Spolsky, Bernard. 2010. Sociolinguistics. Oxford: Oxford University Press.

Swan, Michael. 2009. Practical English usage. Third Edition. Oxford University Press.

Thomas, Bronwen. 2012. Fictional dialogue: Speech and conversation in the modern and postmodern novel. Lincoln-London: University of Nebraska Press.

Trudgill, Peter. 2000. Sociolinguistics: An introduction to language and society. London: Penguin Books.

Wardhaugh, Ronald. 2010. An introduction to sociolinguistics. New York: Basil Blackwell Inc. 